Кузьмич І.І. Правова екзистенціальність біопатентів - нагальна проблема сучасної інтелектуальної...

DOI: $10.36695 / 2219-5521.4 .2019 .47$

УДК 347.77

\title{
I.I. КУЗЬМИЧ
}

Ірина Іванівна Кузьмич, аспірант Київського університету права НАН України*

ORCID: 0000-0001-5606-7165

\section{ПРАВОВА ЕКЗИСТЕНЦІАЛЬНІСТЬ БІОПАТЕНТІВ - НАГАЛЬНА ПРОБЛЕМА СУЧАСНОÏ ІНТЕЛЕКТУАЛЬНОÏ ЗАКОНОТВОРЧОСТІ}

Постановка проблеми. Сучасні тенденції розвитку біотехнологій, що є засобом ринкової політики, де структурно-функціональний показник зростання світового ринку має щорічний приріст у середньому на 7 \%, підійшли до межі, коли охорона прав інтелектуальної власності на біотехнології потребує комплексного науково-практичного дослідження, яке відсутнє на сьогоднішній день. Специфічність та унікальність об'єктів інтелектуальної власності на біотехнології, певні поняття в національному законодавстві, засновані на міжнародних патентних і сортових конвенціях, створили невизначеність щодо захисту біотехнологічних та деяких мікробіологічних винаходів. Взаємодоповнюючі статті Директиви 98/44/СС Європейського парламенту та Ради СС від 06 липня 1998 р. «Про правовий захист біотехнологічних винаходів», Директиви 2004/48/СС Свропейського Парламенту і Ради ЄС «Про забезпечення прав на інтелектуальну власність» від 29 квітня 2004 р., рішення конкуруючих новел міжнародного законодавства та відсутність чітких визначень біотехнологій як об'єктів інтелектуальної власності, враховуючи правову екзистенціальність (унікальність, індивідуальність прим. автора) біопатентів, позначилися на суперечливих спірних питаннях у забезпеченні механізмів охорони прав інтелектуальної власності на біотехнології, закладених, зокрема, у Законі України «Про охорону прав на сорти рослин» від 21 квітня 1993 р. за № 3116-XII, Законі України «Про Загальнодержавну програму адаптації законодавства України до законодавства Свропейського Союзу» від 18 березня 2004 р. за № 1629-IV, та Угоді «Про асоціацію між Україною, з однієї сторони, та Європейським Союзом, Європейським співтовариством 3 атомної енергії і їхніми державами-членами, з іншої сторони» від 27 червня 2014 р. 3 № 984 011, щодо виключення $з$ патентоспроможності сортів рослин і тварин, по суті, біологічних процесів виробництва рослин і тварин, що є дієвою перешкодою для гармонізації положень національного й міжнародного законодавств. Руйнівними наслідками зазначеної проблеми є неповноцінність правових регуляторів харчової та сільськогосподарської біотехнології, яка застосовує генетичну інженерію, трансгенні рослини і тварин, генетичну модифікацію.

Аналіз останніх досліджень і публікацій. Звертаючи увагу на значущість теоретичних розробок механізму захисту прав інтелектуальної власності таких вчених 1 , як О.В. Безух, Ю.Л. Бошицький, М.К. Галянтич, I.I. Дахно, В.А. Дозорцев, В.С. Дроб'язко, В.О. Жаров, А.О. Кодинець, В. Коссак, О.В. Кохановська, О.М. Мельник, Н.М. Мироненко, О.П. Орлюк, О.А. Підопригора, О.П. Сергєєв, О.І. Харитонова, Г.Ф. Шершеневич, Ю.С. Шемшученко, Р.Б. Шишка; проблематику сучасної адміністративно-правової охорони інтелектуальної власності - предмета досліджень О.М. Головкової, І.Г. Запорожця, Н.О. Можаровської, Л.Т. Комзюк, Г.В. Корчевного та інших; питання кримінально-правової охорони та захисту інтелектуальної власності, досліджені П.С. Берзіним та А.С. Нерсеяном; варто визначити доведену наявність принципового етапу консолідуючої основи необхідності правового забезпечення недоторканності й непорушності захисту прав інтелектуальної власності у державі, із застосуванням заходів примусового характеру, спрямованих на відновлення цих прав 2 .

Втім, беручи за основу унікальність, специфічність, неоднорідність біотехнологій, вітчизняні та зарубіжні науковці, вказуючи у своїх дослідницьких роботах на деякі аспекти проблематики економічного та правового забезпечення розвитку біотехнологій, а саме: Дж. Бартон, К. Ведовелло, Б. Карлсон, Л. Крачок, Р. Креспі, П. Респор, О. Слободян, Т. Швед, К. Фрімен, М. Холм, С. Якобсон; а також у працях стосовно співвідношення регулювання прав інтелектуальної власності та охорони громадського здоров'я, зокрема: І. Демченка, Є. Грекова, О. Кашинцевої, В. Муравйова, А. Олефіра, Д. Чибісова тощоㄱ, сприяють з'ясуванню основних категорій правового статусу і регулювання сфери біотехнологій в Україні, економічних та правових недоліків системи нормативного регулювання на національному та міжнародному рівні, із звуженим врахуванням етимології біотехнології як оманливості у правовій векторності ${ }^{4}$.

Однак і дотепер у вітчизняній юридичній науці не було зроблено спеціальних комплексних еквівалентних досліджень проблем уніфікації та гармонізації права інтелектуальної власності в Свропейському Союзі в контексті генезису й перспектив розвитку цієї комунітарної правової сфери в системі права ЄС, проблем адаптації, так званого «поступового наближення» українського законодавства до правової системи ЄС, зокрема, проблем біопатентування, де складність полягає в специфіці та унікальній неоднородності саме об'єктів інтелектуальної власності на біотехнології, здатних саморепродукуватися та самовідтворюватися.

(C) I.I. Кузьмич, 2019

* Iryna Kuzmych, Postgraduate student of Kyiv University of Law of the NAS of Ukraine 
Формулювання мети статті. Мета даної статті полягає у здійсненні спроби дослідити правову екзистенціальність біопатентів й охарактеризувати значення особливостей суті біотехнологій як об'єктів інтелектуальної власності, для розуміння обгрунтування обумовленості процедури патентування, враховуючи дану специфіку на етапі створення нормативно-правового підгрунтя, закладеного, зокрема, у Законі України «Про правову охорону рослин» від 21 квітня 1993 р. за № 3116-XII (редакція від 04.10.2018 р., підстава 2530-VIII), й розкрити підходи міжнародно-правових актів у частині закріплення принципів захисту прав інтелектуальної власності, таких як Конвенція про охорону біологічного різноманіття від 1992 р. за № 995_030, (редакція від 29.10.2010 р., підстава 995 k03) (далі - Конвенція), Угода про торговельні аспекти прав інтелектуальної власності (далі - ТРІПС) від $1 \overline{5}$ квітня 1994 р., Регламент Ради Свропейського Союзу 2100/94 «Про права на селекційні досягнення у Свропейському Співтоваристві» від 27 липня 1994 р., Директива 98/44/СС від 06 липня 1998 р., Директива 2004/48/ЄС Європейського Парламенту і Ради ЄС «Про забезпечення прав на інтелектуальну власність» від 29 квітня 2004 р. (м. Страсбург) та визначити особливості їх реалізації в національному законодавстві, а саме: у постанові КМУ «Про Концепцію адаптації законодавства України до законодавства Європейського Союзу» від 16 серпня 1999 р. за № 1496 (редакція від 21.05.2003 р., підстава 716-2003-п), Законі України «Про Загальнодержавну програму адаптації законодавства України до законодавства Європейського Союзу» від 18 березня 2004 р. за № 1629-IV (редакція від 04.11.2018 р., підстава 2581-VIII) та Угоді «Про асоціацію між Україною, з однієї сторони, та Європейським Союзом, Європейським співтовариством $з$ атомної енергії і їхніми державами-членами, з іншої сторони» від 27 червня 2014 р. за № 984_011 (редакція від 30.11.2015 р., підстава v2980321-15) (далі - Угода про асоціацію).

Виклад основного матеріалу. 3'ясовано, що джерела права Європейського Союзу і Європейських співтовариств ілюструють всю неоднорідність та багатошаровість самої нормативно-інституціональної системи Союзу і Співтовариств, яка підтверджує полісистемність європейської нормативної структури. Так, Угода про торговельні аспекти прав інтелектуальної власності (далі - ТРІПС) від 15 квітня 1994 р. містить, зокрема, положення про засоби забезпечення прав на інтелектуальну власність, які є загальними стандартами, що застосовуються на міжнародному рівні і здійснюються в усіх державах-членах $\mathrm{CC}^{5}$. Також, відповідно до п. 8, 9 Директиви № 2004/48/ЄС Європейського парламенту і Ради ЄС «Про забезпечення прав на інтелектуальну власність» зазначено, що невідповідності між системами держав-членів СС щодо способів здійснення прав на інтелектуальну власність завдають шкоди нормальному функціонуванню внутрішнього ринку, і це унеможливлює гарантію того, що права на інтелектуальну власність здійснюються еквівалентно рівню захисту даних прав на всій території Співтовариства 6 . Така ситуація перешкоджає вільному пересуванню в межах внутрішнього ринку, а також створенню сприятливих умов для здорової конкуренції. Це також призводить до ослаблення матеріального права на інтелектуальну власність і дроблення внутрішнього ринку в цій галузі, що зумовлює втрату впевненості у внутрішньому ринку в ділових колах із подальшим скороченням капіталовкладення в інноваційну та творчу діяльність.

Так, згідно зі ст. 7 «Цілі» частини першої «Загальні положення та основні принципи» Угоди ТРІПС, захист і контроль за дотриманням прав інтелектуальної власності повинні сприяти запровадженню технологічних нововведень та передачі й розповсюдженню технологій для обопільної вигоди виробників і користувачів технологічних знань у такий спосіб, що сприяє соціальному та економічному добробуту, а також балансу прав і обов'язків 7 . Саме таким правовим інструментом охорони прав інтелектуальної власності є патент, який являє собою узаконений документ, що забезпечує виняткові права власника патенту на комерційне використання винаходу, де патент - це загальнодоступний документ, який містить докладний опис винаходу i, таким чином, інформує треті особи про сутність нововведення і його обмеження. Це допомагає їм вирішити питання, чи варто продовжувати роботу в даному напрямі, чи/або ж спробувати використовувати запатентований винахід як стартовий майданчик для інших можливих розробок. Тобто стратегія, яка об'єднує інтереси обох сторін, полягає в тому, що держава надає винахідникам виключні права на нові продукти або способи їх отримання. Так, відповідно до п. 3 ст. 27 «Патентоспроможні об'єкти» Розділу 5 «Патенти» частини другої ТРІПС члени можуть не дозволяти патентування, зокрема, рослин та тварин, крім мікроорганізмів, та важливих біологічних процесів для продукування рослин або тварин, крім небіологічних та мікробіологічних процесів, однак повинні забезпечити захист сортів рослин або через патенти, або sui generis ефективну систему, або завдяки їх комбінації, із правом перегляду цього положення через чотири роки після набрання чинності Угодою СОТ ${ }^{8}$. Тому, у ст. 5 «Об'єкт прав на селекційні досягнення у Європейському Співтоваристві», ст. 6 «Охоронювані селекційні досягнення» Регламенту Ради Європейського Союзу 2100/94 «Про права на селекційні досягнення у Європейському Співтоваристві» зазначено, що об'єктом прав на селекційні досягнення, які повинні бути індивідуальними, однорідними, стабільними й новими, є різновиди всіх ботанічних сортів і видів, включаючи, поміж іншим, і гібриди сортів та видів рослин. До того ж, термін «сорт рослин» повинен використовуватися для позначення групи рослин в межах одного ботанічного таксону найнижчого відомого класу, чия класифікація, незалежно від того, чи повністю дотримуються умови для надання права на селекційні досягнення, зокрема, може бути визначена за допомогою характеристик, що виникають в результаті даного генотипу чи/або комбінації генотипів 9 .

Зважаючи на положення Директиви 98/44/ЄС «Про правову охорону біотехнологічних винаходів» від 06 липня 1998 р. (далі - Директива) у п. 1 ст. 3 нові винаходи, які передбачають винахідницьку стадію та які піддаються промисловому застосуванню, підлягають патентуванню, навіть якщо вони стосуються продукту, який складається з біологічного матеріалу, що містить його, або процесу, за допомогою якого біологічний 
матеріал виробляється, переробляється або використовується. При цьому біологічний матеріал, виділений із природного середовища або отриманий технічним процесом, може бути предметом винаходу, навіть якщо він раніше відбувся в природі, де (а) «біологічний матеріал» означає будь-який матеріал, що містить генетичну інформацію і здатний відтворювати себе або відтворюватися в біологічній системі; (b) «мікробіологічний процес» означає будь-який процес, що включає або проводить на мікробіологічному матеріалі або в результаті цього. До того ж, беручи до уваги, що у п. 30-32 Директиви тлумачення поняття «сорт рослин» визначається законодавством, що захищає нові сорти, згідно з яким сорт визначається цілим геномом і, отже, має індивідуальність та чітко відрізняється від інших сортів. Також, враховуючи, що рослинне угруповання, яке характеризується певним геном (а не всім його геномом), не охоплюється захистом нових сортів і тому не виключається 3 патентоспроможності, навіть якщо воно включає нові сорти рослин. Однак, при цьому, якщо винахід полягає лише в генетичній модифікації певного сорту рослин і якщо новий сорт рослин буде розведений, він все одно буде виключений з патентоспроможності, навіть якщо генетична модифікація результат не по суті біологічного процесу, а є біотехнологічним процесом ${ }^{10}$. Вочевидь, маємо відсутність чіткого визначення як рослинних угруповань, так і відмінностей біологічного від біотехнологічного процесу.

Відсутнє понятійно-категоріальне визначення і живих змінених організмів, представлених у п. 3 ст. 19 «Застосування біотехнології та розподіл пов’язаних з нею вигод» Конвенції. Принаймні, йдеться про необхідність і умови прийняття заходів, можливо, у формі протоколу, включаючи, зокрема, попередньо обгрунтовану згоду, з розробки відповідних процедур у галузі безпечної передачі, використання й застосування будь-яких живих змінених організмів, що є результатом біотехнології і здатні спричинити несприятливий вплив на збереження і стале використання біологічного різноманіття. При цьому у ст. 16 «Доступ до технології та ï передача» із зазначенням патентування генетичних ресурсів і технології, обумовленої патентами та іншими правами інтелектуальної власності, такий доступ і передача забезпечуються на умовах, які враховують достатню й ефективну охорону прав інтелектуальної власності і відповідають їй - без жодних з'ясувань конкретизації достатньої та ефективної охорони, що, відповідно, вимагає уточнення механізму правового захисту біотехнологічних винаходів. Стаття 8 «Збереження in-situ», де «Умови in-situ» означають умови, в яких існують генетичні ресурси в рамках екосистем і природних місць мешкання, а у випадку акліматизованих або культивованих видів - у тому середовищі, в якому вони набули свої характерні ознаки, свідчить про встановлення або підтримку заходів регулювання, контролю або обмеження ризику, пов'язаного 3 використанням і звільненням живих організмів, які є результатом біотехнології, що можуть мати шкідливі екологічні наслідки, здатні впливати на збереження і стале використання біологічного різноманіття, 3 урахуванням також небезпеки для здоров'я людини ${ }^{11}$.

Природна здатність даної групи бактерій синтезувати і виводити з клітин цілий ряд важливих метаболітів, які можуть застосовуватися в промисловості, сільському господарстві та медицині, а також такі характеристики цих бактерій, як стабільність при зберіганні, технологічність у процесі виробництв і екологічна безпека, робить бацили найважливішим об'єктом промислової біотехнології. Вивчення опису векторних систем і способів введення генетичного матеріалу в клітини бацил, а також аналіз сучасних методів отримання рекомбінантних штамів на їх основі, доводить, що не є таксономічною категорією, найнижчим таксоном у всіх організмів є вид, а один і той же штам не може бути виділений другий раз з того ж джерела в інший час. До того ж, у світі не існує загальновизнаної номенклатури назви штамів, і використовувані назви досить довільні. Штам (від нім. Stamm, буквально - «ствол», «рід») - чиста культура вірусів, бактерій, інших мікроорганізмів або культура клітин, ізольована в певний час і в певному місці12.

Виходячи з вищезазначеного, патентна охорона винаходів у галузі біотехнології з використанням штамів має низку особливостей. По-перше, як показує практика розгляду заявок на винаходи, що належать до штамів мікроорганізмів, консорціумів на їх основі, біопрепаратів, що включають штами мікроорганізмів або частини клітин мікроорганізмів, досить часто подаються заявки, які не містять повної сукупності ознак, що регламентуються діючими Правилами і необхідними для ідентифікації або відтворення заявленого об'єкта, а також не містять необхідного експериментального підтвердження досягнення заявленого технічного результату. Це стає причиною тривалої переписки експертів із заявниками через необхідність запиту додаткових матеріалів. Наприклад, якщо заявником неповно охарактеризовані культуральні, морфологічні ознаки штаму або рівень його продуктивності, то за запитом експертизи такі дані, як правило, надаються заявниками і згодом включаються в текст опису як описові характеристики штаму. По-друге, на думку експертів, тільки за описом штаму, що міститься в заявці на винахід, неможливо його здійснення. Сдиною можливістю для підтвердження здійсненності, тобто промислової придатності такого об'єкта винаходу, як «штам», може виявитися депонування.

Депонування для цілей патентної процедури вважається здійсненим, якщо штам, вміщений в сховище міжнародного органу по депонуванню, передбачений Будапештським договором Про міжнародне визнання депонування для цілей патентної процедури, або до уповноваженої на їх депонування української колекції, яка гарантує підтримку життєздатності об'єкта протягом, щонайменше, терміну дії патенту і задовольняє інші встановлені вимоги до колекцій, що здійснює депонування для цілей патентної процедури. Саме тому загальновизнано, що найбільш вірогідний спосіб підтвердження можливості здійснення винаходу щодо об’єкта винаходу «штам» - це депонування штаму у спеціалізованій колекції, що має певний статус. Вказівку на таке депонування у колекції-депозитарії включено у Правила депонування мікроорганізмів при подачі заявок на винаходи. При цьому дата депонування має передувати даті пріоритету винаходу. Так, у складі 
Української колекції мікроорганізмів для забезпечення, відповідно до Державної фармакопеї України, потреб підприємств та інститутів у штамах мікроорганізмів для проведення контролю якості лікарських засобів створена колекція референтних тест-штамів, зокрема, в Інституті мікробіології і вірусології ім. Д.К. Заболотного НАН України (м. Київ) - 38 тест-штаммів для контролю якості лікарських засобів ${ }^{13}$.

Отже, заявнику надається альтернатива або депонувати штам, або розкривати спосіб його отримання таким чином, щоб будь-яка третя особа могла його відтворити. Однак часто навіть найдокладніший опис штаму і способу його отримання не дає змоги відтворити відповідний винахід, особливо, якщо йдеться про штами, виділені з будь-якого природного джерела. Насамперед тому, що джерело може припинити своє існування або змінитися в такий спосіб, що відповідний штам вже не зможе бути з нього отримано. Крім того, в даній ситуації швидше можна гарантувати отримання біологічного об'єкта певного роду або виду, але не конкретного заявленого штаму.

Враховуючи необхідність гармонізації для уточнення зазначеної невизначеності, доречно розглянути транспозиції в національне законодавство, де з часу приєднання (02.06.1995 p.; 02.08.2006р.) України до Міжнародної конвенції з охорони нових сортів рослин від 02 грудня 1961 р. (Конвенція УПОВ) досягнуто значних успіхів у забезпеченні конституційних прав громадян володіти і розпоряджатися результатами своєї інтелектуальної власності на сорти рослин ${ }^{14}$. Створено законодавчу базу, яка забезпечує ефективне функціонування системи охорони прав інтелектуальної власності на сорти рослин, зокрема їх набуття, здійснення та захисту. Угодою про партнерство і співробітництво між Україною і Європейськими Співтовариствами та їх державами-членами від 14 червня 1994 р., а також Концепцією адаптації законодавства України до законодавства Свропейського Союзу визначено пріоритетні сфери адаптації законодавства, від зближення яких залежить зміцнення економічних зв'язків України та держав-членів СС, і які регулюють відносини, пов'язані 3 охороною прав інтелектуальної власності ${ }^{15}$. Ймовірно, міжнародно-правові акти $є$ носієм рекомендаційного характеру у забезпеченні охорони прав інтелектуальної власності, зокрема, на біотехнології, тоді як, беручи до уваги вищевикладене щодо специфічності, правової екзистенціальності біопатентів, де закон повинен нести важливу за змістом інформацію, бути інструкцією здійснення чітких дій у контексті правової трансформації у даній сфері, некомпетентність для українського законодавця неприпустима.

Так, згідно 3 п. 4 ст. 221 «Охорона винаходів у галузі біотехнологій» Підрозділу 5 «Патенти» Угоди про асоціацію, винаходи, які стосуються рослин і тварин, $\epsilon$ патентоспроможними, коли технічна можливість реалізації винаходу не обмежується конкретним сортом рослини або породою тварини. Підпункт (b) цього пункту, а саме суттєво важливі для відтворення рослин і тварин біологічні процеси, не завдає шкоди патентоспроможності винаходів, що стосуються мікробіологічних або інших технічних процесів чи продуктів, одержаних за допомогою таких процесів, де їх комерційне використання не суперечить ordre public (публічному порядку) або суспільній моралі. До того ж, відповідно до ст. 220 «Додатковий охоронний сертифікат», продукція, призначена для захисту здоров'я та рослин, що охороняється патентами на відповідній території сторін даної Угоди, може підлягати адміністративній процедурі надання дозволу перед випуском на ринок. I проміжок часу, який проходить від дати подання заявки на патент до одержання першого дозволу випускати продукт на їхній відповідний ринок у порядку, встановленому відповідним законодавством, може скоротити період ефективної охорони згідно 3 патентом ${ }^{16}$.

Виходячи із визначення об’ єкта винаходу (корисної моделі) у п. 2 ст. 6 «Умови надання правової охорони» Розділу II «Правова охорона винаходів (корисних моделей)» Закону України «Про охорону прав на винаходи (корисні моделі)» від 15 грудня 1993 р. за № 3687-XII, таким може бути: «продукт (пристрій, речовина, штам мікроорганізму, культура клітин рослин і тварини, тощо), процес (спосіб), а також нове застосування відомого продукту чи процесу». Характерно, що оскільки багато мікроорганізмів розмножуються бінарним поділом (простий поділ клітини, властивий бактеріям) або митозом (еукаріотичні мікроорганізми, такі, як гриби, водорості), без участі статевого процесу, по суті, види у таких мікроорганізмів складаються із клональних ліній, генетично і морфологічно ідентичних вихідній клітці, де віднесення мікроорганізму до певного виду відбувається на основі досить широких ознак. Таким чином, враховуючи багатогранність та унікальність інтелектуального біомедпродукту, зрозуміла очевидна необхідність виділення охорони прав інтелектуальної власності на біотехнології в окремий Закон, як ланку низки вітчизняних нормативно-правових актів, якою було б передбачено запровадження релевантного механізму координації всіх державних інституцій, до компетенції яких належать питання захисту прав інтелектуальної власності, у тому числі МВС, СБУ, Міністерства юстиції України, Державної митної служби, Держкомтелерадіо та інших ${ }^{17}$.

Відповідно до Розділу II «Визначення термінів» Закону України «Про Загальнодержавну програму адаптації законодавства України до законодавства СС», адаптація законодавства - процес приведення законів України та інших нормативно-правових актів у відповідність з acquis communautaire, де acquis communautaire (acquis) - правова система Європейського Союзу, яка включає акти законодавства Європейського Союзу (але не обмежується ними), прийняті в рамках Європейського співтовариства, Спільної зовнішньої політики та політики безпеки і Співпраці у сфері юстиції та внутрішніх справ. До речі, у Розділі V «Мета та завдання першого етапу виконання програми» у переліку пріоритетних сфер, визначених ст. 51 УПС (998_012), в яких має бути здійснена адаптація законодавства, інтелектуальна власність на шостому місці, а на одинадцятому - охорона здоров'я та життя людей, тварин і рослин, - в одному пункті, разом ${ }^{18}$.

Безперечно, такими регуляторними нормативними актами, як проект наказу від 11 серпня 2017 р. за № 37-13-6-7/18900 Міністерства аграрної політики та продовольства України, відповідно до частини другої 
Кузьмич І.І. Правова екзистенціальність біопатентів - нагальна проблема сучасної інтелектуальної...

ст. 9 Закону України «Про охорону прав на сорти рослин», п. 8 Положення про Міністерство аграрної політики та продовольства України, затвердженого постановою Кабінету Міністрів України від 25 листопада 2015 р. за № 1119, про затвердження Порядку підтвердження підприємствами, установами, організаціями відповідного рівня компетентності, вимоги щодо кількості кваліфікованого персоналу, який працює на постійній основі, вимоги до фінансових та матеріальних ресурсів, акредитованих лабораторій та системи управління якістю, переліку документів, необхідних для отримання уповноваження, та порядок їх подачі, упорядковуються механізми охорони прав на сорти рослин, як об'єктів інтелектуальної власності ${ }^{19}$. Так, Наказ Міністерства аграрної політики та продовольства України від 26 жовтня 2017 р., зареєстрований у Міністерстві юстиції України 26 лютого 2018 р. за № 232/31684 «Про затвердження Інструкції щодо забезпечення дослідними зразками експертизи заявки на сорт рослин», створений, відповідно до ст. ст. 20,29 Закону України «Про охорону прав на сорти рослин», підпункту 21 п. 4 Положення про Міністерство аграрної політики та продовольства України, затвердженого постановою Кабінету Міністрів України від 25 листопада 2015 р. за № 1119, п. 16 Положення про державну реєстрацію нормативно-правових актів міністерств, інших органів виконавчої влади, затвердженого постановою Кабінету Міністрів України від 28 грудня 1992 р. за № 731, та з метою приведення нормативно-правових актів у відповідність до вимог чинного законодавства, - скасовуючи попередні Інструкції, встановлює порядок постачання та вимоги до дослідних зразків сортів, які надаються для експертизи заявки на сорт рослин. До того ж, експертний заклад, 3 метою впорядкування постачання й отримання зразків для цілей експертизи, у своєму складі визначає спеціалізований структурний підрозділ, основним завданням якого є реєстрація супровідних документів, облік зразків, перевірка супровідних документів, проведення підготовчих робіт з фасування, пакування, протруєння, постачання зразків до пункту дослідження, зберігання тощо 20.

Також впровадження дистанційного навчання з 05-08 березня 2018 р., таких як DL-205 «Вступ до системи охорони сортів рослин UPOV згідно з Конвенцією UPOV», DL-305 А «Адміністрування прав селекціонера» (Частина A DL-305 курсу: «Експертиза заявок на права селекціонера»), DL-305 В «Експертиза на BOC» (Частина B DL-305 «Експертиза заявок на права селекціонера») та DL-305 «Експертиза заявок на права селекціонера», організовані Міжнародним союзом з охорони нових сортів рослин на платформі Центру електронного навчання Всесвітньої організації з інтелектуальної власності (WIPO) є яскравими показниками імплементації у контексті Угоди про асоціацію України і СС підписаної 21 березня і 27 червня 2014 р. (Брюссель, Бельгія), де ратифікація з боку Свросоюзу 11 липня 2017 р., чинна (остаточно, деякі положення вступили раніше) з 01 вересня 2017 р., дата підготовки - 330 березня 2012 року21.

Проектом Закону України «Про внесення змін до деяких законодавчих актів України щодо підвищення рівня охорони і захисту прав інтелектуальної власності на винаходи (корисні моделі), промислові зразки і торговельні марки» від 20 вересня 2018 р. (оновлена версія від 01.02.2018 р. за № 7538) у частині другій і третій ст. 6 передбачається, що об'єктом винаходу, правова охорона якому (якій) надається згідно $з$ цим Законом, може бути продукт (пристрій, речовина, штам мікроорганізму, культура клітин рослини і тварини тощо), процес (спосіб), а також нове застосування відомого продукту чи процесу. Об'єктом корисної моделі, правова охорона якій надається згідно з цим Законом, є пристрій ${ }^{22}$. А правова охорона згідно $з$ цим Законом не поширюється на такі об'єкти, як сорти рослин і породи тварин; біологічні у своїй основі процеси відтворення рослин та тварин, що не належать до небіологічних та мікробіологічних процесів, а також продукту такого процесу тощо 23 .

Висновки. Важко переоцінити роль патентної документації, що дає змогу виявляти альтернативні технології, якими можна замінити менш сучасні технології, підприємства, що діють у тій чи іншій сфері технологій, знаходити рішення технічних проблем, проводити експертизу науково-технічних програм, визначати пріоритетні напрями розвитку галузей промисловості й окремих виробництв, а також містить технічну, технологічну й правову інформацію, дає можливість не дублювати виконану іншими роботу, заощаджуючи час, фінанси, сили в процесі науково-дослідної діяльності, для патентоволодільця у просуванні винаходу на ринку.

Враховуючи зазначене, а також те, що однією з нагальних проблем законодавства України у сфері інтелектуальної власності на біотехнології в цілому є іiі надмірна розгалуженість, з одного боку, вбачається недоцільним вносити фрагментарні зміни до законодавства з метою імплементації положень лише міжнародних норм без урахування директив та регламентів ЄС. Проте, з іншого боку, беручи до уваги, що відповідно до частини другої ст. 292 «Багатосторонні угоди 3 охорони навколишнього середовища» Глави 13 «Торгівля та сталий розвиток» Угоди про асоціацію сторони підтверджують своє зобов'язання щодо ефективної імплементації у своїх законах та практиках багатосторонніх угод з охорони навколишнього середовища, учасницями яких вони $\epsilon$, законопроект за результатами розгляду в першому читанні може бути прийнятий за основу.

Таким чином, вітчизняна правова парадигма для здійснення контролю інтелектуальної власності на біотехнології недостатньо сформована із-за відсутності національних законодавчих інструментів. Слід застерегти, що міжнародно-правові акти сформульовані під комерціалізовані відносини, де європейське партнерство надає не тільки багатий законодавчий досвід, а й має імперативний характер, посилюючи в Україні пригнічення початкових ринкових зусиль із збереженням морально-етичних підвалин у такому складному правовому аспекті, як здійснення контролю за інтелектуальним біомедпродуктом. - шлях відстоювання прав і свобод для громадян своєї країни, право вибору національної державної позиції. 
На наш погляд, правова система України має створити сприятливі умови для гармонізації міжнародноправових актів у вітчизняне законодавство, а саме на теоретичному етапі створювати нормативно-правову базу з урахуванням національних особливостей, правового менталітету, де постануть правові механізми охорони й контролю об'єктів і суб'єктів інтелектуальної власності на біотехнології. Однак без ефективних засобів забезпечення прав на інтелектуальну власність інноваційна та творча діяльність не підтримуються і капіталовкладення зменшується. У зв'язку з цим необхідно забезпечити, щоб матеріальне право в галузі інтелектуальної власності, яке в даний час значною мірою є частиною acquis communautaire, ефективно застосовувалося в Співтоваристві. У цьому відношенні засоби забезпечення прав на інтелектуальну власність мають першорядне значення для успіху внутрішнього ринку. Для досягнення необхідного результату потрібно об'єднання зусиль законодавчої вертикалі із висококваліфікованими фаховими спеціалістами у сфері біотехнологій, де даний взаємозв'язок із спеціалістами законотворчості приречений на відтворення належного вітчизняного правового імунітету.

${ }^{1}$ Бошицький Ю.Л., Швантнер М. Сучасна концепція стратегії інтелектуальної власності : загальні питання теорії, методології та практики. Часопис Київського університету права. 2015. № 1. C. 195-200. URL: http://www.irbis-nbuv.gov.ua/cgi-bin/ irbis_nbuv/cgiirbis_64exe?I21DBN=LINK\&P21DBN=UJRN\&Z21ID=\&S21REF=10\&S21CNR=20\&S21STN=1\&S21FMT=ASP meta\&C21COM=S\&2_S21P03=FILA=\&2_S21STR=Chkup_2015_1_49

2 Павленко Т.А. Особливості захисту права інтелектуальної власності в сучасній Україні Наме право. 2014. № 10. С. 147152. URL: http://www.irbis-nbuv.gov.ua/cgi-bin/irbis_nbuv/cgiirbis_64.exe?C21COM=F\&I21DBN=UJRN\&P21DBN=UJRN5

3 Олефір А.О. До проблеми правової охорони біотехнологій. Теорія і практика інтелектуальної власності : наук.-практ. журн. / Н.-д. ін-т інтелектуальної власності Нац. акад. прав. наук України. Київ, 2015. № 1. С. 71-83. URL: http://nbuv.gov.ua/ UJRN/Tpiv 2015 1_10

4 Кузьмич I.I. Міжнародно-правові акти у сфері правової охорони інтелектуальної власності на біотехнології. Часопис Київського університету права. 2018. № 2. С. 219-226. URL: http://www.irbis-nbuv.gov.ua/cgi-bin/irbis_nbuv/cgiirbis_64.exe? $\mathrm{I} 21 \mathrm{DBN}=\mathrm{LINK} \& \mathrm{P} 21 \mathrm{DBN}=\mathrm{UJRN} \& Z 21 \mathrm{ID}=\& \mathrm{~S} 21 \mathrm{REF}=10 \& \mathrm{~S} 21 \mathrm{CNR}=20 \& \mathrm{~S} 21 \mathrm{STN}=1 \& \mathrm{~S} 21 \mathrm{FMT}=\mathrm{ASP}$ meta\&C $21 \mathrm{COM}=\mathrm{S} \& 2$ $03=$ FILA $=\& 2 \_S 21 \mathrm{STR}=$ Chkup_2015_1_49

5 Угода про торговельні аспекти прав інтелектуальної власності № 981054 від 15.04. 1994 р. (поточна редакція від 06.12.2005 р., документ № 981_018). URL: http://zakon.rada.gov.ua/laws/show/981 018

6 Про забезпечення прав на інтелектуальну власність: директива 2004/48/ЄС С Єропейського Парламенту і Ради ЄС від 29.04.2004 р. (м. Страсбург), п. 8, 9. URL: https://zakon.rada.gov.ua/laws/main/994_b39

7 Угода про торговельні аспекти прав інтелектуальної власності № 981_054 від 15.04. 1994 р. (поточна редакція від 06.12.2005 р., документ № 981_018), п. 7, ч. I. URL: http://zakon.rada.gov.ua/laws/show/981_018

8 Там само.

9 Про права на селекційні досягнення у Європейському Співтоваристві: регламент Ради Свропейського Союзу 2100/94 від 27.07.1994 р., ст. ст. 5, 6. URL: http://base.garant.ru/2570154/

10 Про правову охорону біотехнологічних винаходів: директива 98/44/ЄС Європейського Парламенту та Ради від 06.07.1998 р. Офічійний вісник СС, L 213. 1998. 30 липня. С. 13-21. П. 1. Ст. 3. П.п. 30-32. URL: https://eur-lex.europa.eu/legalcontent/EN/TXT/?uri=celex\%3A31998L0044

${ }^{11}$ Конвенція про охорону біологічного різноманіття від 1992 р. № 995_030 (редакциія від 29.10.2010 p., nidcmaвa 995_k03) п. 3 ст. 19, ст.16, ст. 8. URL: http://zakon.rada.gov.ua/laws/show/995 030

12 Каленова Л.Ф. Вплив вторинних метаболітів Bacillus sp. $\overline{3}$ багатолітнємерзлих порід на синтез цитокінів мононуклеарними клітинами периферичної крові людини / за ред. Каленова Л.Ф., Коливанова С.С., Бажин А.С., Бесєдін І.М., Мельникова В.П. Бюлетень експериментальної біології і медицини. 2017. Т. 163. № 2. URL:https://www.utmn.ru/presse/novosti/naukasegodnya/612060/

13 Колекція референтних тест-штамів. Інститут мікробіологї і вірусології ім. Д.К. Заболотного НАН Украӥни (м. Київ) 38 тест-штамів для контролю якості лікарських засобів. URL: http://www.imv.kiev.ua/index.php/ru/shtam

14 Міжнародна конвенція з охорони нових сортів рослин від 02.12.1961 р. (приєднання України від 02.06.1995 р.; 02.08.2006 р.), документ 995856 (поточна редакція 02.08.2006, підстава 60-V). URL: https://zakon.rada.gov.ua/laws/main/995_856

15 Про Концепцію адаптації законодавства України до законодавства Свропейського Союзу: постанова КМУ від 16.08.1999 p. № 1496 (редакція від 21.05.2003 р., підстава 716-2003-п). URL: https://zakon.rada.gov.ua/laws/main/1496-99-п

16 Угода про асоціацію між Україною, з однієї сторони, та Європейським Союзом, Європейським співтовариством 3 атомної енергії і їхніми державами-членами, з іншої сторони від 27.06.2014р., документ 984_011 (поточна редакція 30.11 .2015 р., підстава - v2980321-15), ст. 220, п. 4, ст. 221, підрозділ 5. URL: https://zakon3.rada.gov.ua/1aws/show/984_011

17 Про охорону прав на винаходи (корисні моделі): Закон України від 15.12.1993 р. № 3687-ХІІ (поточна редакція 05.12.2012 р., підстава 5460-VI), п. 2, ст. 6, Розділ II. URL: https://zakon.rada.gov.ua/laws/main/3687-12

18 Про Загальнодержавну програму адаптації законодавства України до законодавства Європейського Союзу: Закон України від 18.03.2004 р. № 1629-IV (редакція від 04.11.2018 р., підстава 2581-VIII), Розділи II, V. URL: https://zakon.rada. gov.ua/laws/show/1629-15

19 Наказ від 11.08.2017 р. № 37-13-6-7/18900 Міністерства аграрної політики та продовольства України (відповідно до частини другої статті 9 Закону України «Про охорону прав на сорти рослин», пункту 8 Положення про Міністерство аграрної політики та продовольства України), затверджений постановою Кабінету Міністрів України від 25.11. 2015 p. № 1119. URL: https://zakon.rada.gov.ua/laws/main/z0781-18

20 Наказ Міністерства аграрної політики та продовольства України від 26.10 .2017 р., зареєстрований у Міністерстві юстиції України 26.02.2018 р. за № 232/31684 Про затвердження Інструкції щодо забезпечення дослідними зразками експертизи заявки на сорт рослин, створений (відповідно до статей 20, 29 Закону України «Про охорону прав на сорти рослин», підпункту 21 пункту 4 Положення про Міністерство аграрної політики та продовольства України), затвердженого постановою Кабінету Міністрів України від 28.12.1992 р. № 731. URL: https://zakon.rada.gov.ua/laws/main/z0232-18 
21 Впровадження дистанційного навчання з 05.03. - 08.03. 2018 року, DL-205 Вступ до системи охорони сортів рослин UPOV згідно з Конвенцією UPOV, DL-305 А Адміністрування прав селекціонера (Частина A DL-305 курсу: Експертиза заявок на права селекціонера), DL-305 В Експертиза на BOC (Частина B DL-305 Експертиза заявок на права селекціонера) та DL-305 Експертиза заявок на права селекціонера (організовані Міжнародною спілкою з охорони нових сортів рослин на платформі Центру електронного навчання Всесвітньої організації з інтелектуальної власності (WIPO). URL: https://zakon.rada.gov.ua/ laws/show/z0703-13/ed20130425

22 Проект Закону України «Про внесення змін до деяких законодавчих актів України щодо підвищення рівня охорони і захисту прав інтелектуальної власності на винаходи (корисні моделі), промислові зразки і торговельні марки» від 20.09.2018 р. (оновлена версія від 01.02.2018 р. за № 7538), ч. II, III, ст. 6. URL: http://www.me.gov.ua/Documents/Detail?lang=uk-UA\&id= 483072a8-5b63-4c8e-a478-4be61a265d1f\&title=ProektZakonuUkrainiproVnesenniaZminDoDeiakikhZakonodavchikhAktiv UkrainiSchodoPidvischenniaRivniaOkhoroniIZakhistuPravIntelektualnoiVlasnostiNaVinakhodi-korisniModeli-PromisloviZrazkiI TorgovelniMarki

23 Юлевич О.І., Ковтун С.І., Гиль М.І. Біотехнологія : навч. посіб. / за ред. М.І. Гиль. Миколаїв : МДАУ. 2012. 476 с.

\section{References:}

Boshytskyi, Yu.L., Shvantner, M. (2015). The Modern Concept of Intellectual Property Strategy: General Issues in Theory, Methodology and Practice. Chasopys Kyyivs koho universytetu prava, 1, 195-200. URL: http://www.irbis-nbuv.gov.ua/cgi-bin/ irbis_nbuv/cgiirbis_64.exe?I21DBN=LINK\&P21DBN=UJRN\&Z21ID=\&S21REF=10\&S21CNR=20\&S21STN=1\&S21FMT=ASP meta\&C21COM=S\&2_S21P03=FILA=\&2_S21STR=Chkup_2015_1_49 [in Ukrainian].

Pavlenko, T.A. (2014). Features of protection of intellectual property rights in modern Ukraine. Nashe pravo, 10, 147-152. URL: http://www.irbis-nbuv.gov.ua/cgi-bin/irbis_nbuv/cgiirbis_64.exe?C21COM=F\&I21DBN=UJRN\&P21DBN=UJRN5 [in Ukrainian].

Olefir, A.O. (2015). To the problem of legal protection of biotechnologies. Theory and Practice of Intellectual Property. Naukovo-praktychnyy zhurnal Naukovo-Doslidnyts 'koho instytutu intelektual noyi vlasnosti Natsional noyi Akademiyi pravnychykh nauk Ukrayiny. ISSN 2308-0361. Kyyiv, 1, 71-83. URL: http://nbuv.gov.ua/UJRN/Tpiv_2015_1_10 [in Ukrainian].

Kuzmych, I.I. (2018). International legal acts in the field of legal protection of intellectual property on biotechnology. Chasopys Kyyivs koho universytetu prava, 2, 219-226. URL: http://www.irbis-nbuv.gov.ua/cgi-bin/irbis_nbuv/cgiirbis_64.exe?I21DBN= LINK\&P21DBN=UJRN\&Z21ID= \&S21REF=10\&S21CNR=20\&S21STN=1\&S21FMT=ASP_meta $\& C 21 \mathrm{COM}=\mathrm{S} \& 2$ _S21P03=FILA $=\& 2 \_$S21STR $=$Chkup_2015_1_49 [in Ukrainian].

Agreement on Trade-Related Aspects of Intellectual Property Rights № 981_054. (1994, April 15). Urugvays `kyy raund Heneral'noyi uhody z taryfiv i torhivli (GATT), 7, I. URL: http://zakon.rada.gov.ua/laws/show/981_018 [in Ukrainian].

Directive 2004/48/EC. (2004, April 29). About securing intellectual property rights. Yevropeys kyy Parlament i Rada YeS. Strasburh: 8, 9. URL: https://zakon.rada.gov.ua/laws/main/994_b39 [in Ukrainian].

Council Regulation (EC) No 2100/94 On selection rights in the European Community. (1994, July 27). Yevropeys 'kyy Parlament i Rada YeS. URL: http://base.garant.ru/2570154/ [in Ukrainian].

Directive 98/44/EC On the legal protection of biotechnological inventions № 31998L0044. (1998, Jule 6). Yevropeys 'kyy Parlament i Rada YeS (OJL 213, 3, pp. 30-32 (ES, DA, DE, EL, EN, FR, IT, NL, PT, FI, SV)). URL:https://eur-lex.europa.eu/legal-content/ $\mathrm{EN} / \mathrm{TXT} /$ ?uri=celex\%3A31998L0044 [in English].

Convention on the Protection of Biological Diversity No. 995_030, (1992). Yevropeys'kyy Parlament i Rada YeS. URL: http://zakon.rada.gov.ua/laws/show/995_030 [in Ukrainian].

Kalenova, L.F., Kolyvanova, S.S, Bazhyn, A.S, Besiedin, I.M, Melnykov, V.P. (2017). Effect of secondary metabolites of Bacillus sp. From perennial frozen rocks for cytokine synthesis by human peripheral mononuclear cells. Byuleten`eksperymental 'noyi biolohiyi i medytsyny. (Vol. 163), 2. URL:https://www.utmn.ru/presse/novosti/nauka-segodnya/612060/ [in Ukrainian].

Collection of reference test strains. 38 test strains for quality control of medicines. (2019). Kyyiv: Instytut mikrobiolohiyi i virusolohiyi im. D.K. Zabolotnoho NAN Ukrayiny. URL: http://www.imv.kiev.ua/index.php/ru/shtam [in Ukrainian].

International Convention for the Protection of New Varieties of Plants № 995_856 (1961, December, 2). Yevropeys`kyy Parlament i Rada YeS. URL: https://zakon.rada.gov.ua/laws/main/995_856 [in Ukrainian].

Resolution On the Concept of Adaptation of the Legislation of Ukraine to the Legislation of the European Union No. 1496. (1999, August, 16). Kabinet Ministriv Ukrayiny. URL: https://zakon.rada.gov.ua/laws/main/1496-99-п [in Ukrainian].

Association Agreement between Ukraine, of the one part, and the European Union, the European Atomic Energy Community and their Member States, of the other part № 984 _011 (2014, June 27). Vidomosti Verkhovnoyi Rady Ukrayiny, 4, 221, 5. URL: https://zakon3.rada.gov.ua/laws/show/984_011 [in Ukrainian].

Law of Ukraine On Protection of Rights to Inventions (Utility Models) No. 3687-XII (1993, December 15). Vidomosti Verkhovnoyi Rady Ukrayiny, 2, 6, II. URL: https://zakon.rada.gov.ua/laws/main/3687-12 [in Ukrainian].

Law of Ukraine On the National Program of Adaptation of the Legislation of Ukraine to the Legislation of the European Union No. 1629-IV. (2004, March 18). Vidomosti Verkhovnoyi Rady Ukrayiny, 29, 367, II,V. URL: https://zakon.rada.gov.ua/laws/show/1629-15 [in Ukrainian].

Order (in accordance with part two of Article 9 of the Law of Ukraine On Protection of Rights to Varieties of Plants, Clause 8 of the Regulation on the Ministry of Agrarian Policy and Food of Ukraine) No. 37-13-6-7 18900. (2017, August 11). Ministerstvo Ahrarnoyi Polityky ta Prodovol'stva Ukrayiny, approved by the Resolution No. 1119. (2015, November, 25). Kabinet Ministriv Ukrayiny. URL: https://zakon.rada.gov.ua/laws/main/z0781-18 [in Ukrainian].

Order On approving the Instruction on provision of examination specimens of the application for a variety of plants, established (in accordance with Articles 20, 29 of the Law of Ukraine On Protection of Rights to Varieties of Plants, 21, 4), (2017, October, 26). Ministerstvo Ahrarnoyi Polityky ta Prodovol'stva Ukrayiny. (2018, February, 26). No. 232/31684. Ministerstvo Yustytsiyi Ukrayiny, approved by the Resolution No. 731. (1992, December, 28). Kabinet Ministriv Ukrayiny. URL: https://zakon.rada.gov.ua/laws/main/ z0232-18 [in Ukrainian]. Implementation of distance learning since. DL-205 Introduction to the UPOV Plant Variety Protection System under the UPOV Convention, DL-305 A Administration of Breeder Rights (Part A DL-305 Course: Examination of Breeder Rights Applications), DL-305 B Examination on BOC (Part B DL-305 Plant Breeder Examination) and DL-305 Plant Breeder Examination. (2018, March, 5-8). Mizhnarodna spilka z okhorony novykh sortiv roslyn na platformi Tsentru elektronnoho navchannya Vsesvitn`oyi orhanizatsiyi z intelektual`noyi vlasnosti (WIPO). URL: https://zakon.rada.gov.ua/laws/show/z0703-13/ed20130425 [in Ukrainian]. 


\section{Проблеми права інтелектуальної власності}

Draft Law of Ukraine On Amendments to Certain Legislative Acts of Ukraine on Enhancing the Protection and Protection of Intellectual Property Rights for Inventions (Utility Models), Industrial Designs and Trademarks No. 7538. (2018, September, 20), Departament Intelektual 'noyi vlasnosni, II, III, 6. URL: http://www.me.gov.ua/Documents/Detail?lang=uk-UA\&id=483072a8-5b634c8e-a478-4be61a265d1 f\&title=ProektZakonuUkrainiproVnesenniaZminDoDeiakikhZakonodavchikhAktivUkrainiSchodoPidvis chenniaRivniaOkhoroniIZakhistuPravIntelektualnoiVlasnostiNaVinakhodi-korisniModeli-PromisloviZrazkiITorgovelniMarki [in Ukrainian].

Yulevych, O.I., Kovtun, S.I., Hyl, M.I. (Ed.) (2012). Biotechnology. Mykolayiv : MDAU [in Ukrainian].

Резюме чості.

Кузьмич I.I. Правова екзистенціальність біопатентів - нагальна проблема сучасної інтелектуальної законотвор-

Надано коротку постатейну деталізацію неоднорідності визначень біотехнологій як об'єктів інтелектуальної власності, а також пов'язаних із ними процесів, у міжнародно-правових актах. Здійснено спробу дослідити правову екзистенціальність біопатентів й охарактеризувати значення особливостей суті біотехнологій для обгрунтування надважливості обумовленості процедури патентування, враховуючи дану специфіку на етапі створення вітчизняного нормативно-правового підгрунтя. Частково розкрито підходи міжнародно-правових актів у частині закріплення принципів охорони і захисту прав інтелектуальної власності на біотехнології як у пріоритетній науково-економічній та державно-стратегічній царині, визначено особливості їх реалізації в національному законодавстві.

Вказано на застереження щодо можливих утворених руйнівних наслідків сучасного некомпетентного підходу з боку вітчизняних законодавців до сутності складу біотехнологій як об'єктів інтелектуальної власності, у створенні механізмів інтелектуальної законотворчості, зважаючи на унікальну здатність біотехнологій саморепродукуватися та самовідтворюватися. Відмічено істотні зміни у поступовому наближенні правових нормативів до стандартів системи права Свропейської спільноти у забезпеченні охорони прав інтелектуальної власності на біотехнології. Відображено розуміння необхідного виокремлення біотехнологій у самостійну правову локальну інтелектуальну сферу цивілізації із певним рівнем відповідальності у перспективі появи ключової інноваційної правової моделі при уніфікованій законотворчій спіралі.

Ключові слова: правова екзистенціальність, інтелектуальна законотворчість, система права ЄС, трансформація, гармонізація, біотехнології, унікальність, специфічність, біопатенти, некомпетентність, застереження.

\section{Резюме}

Кузьмич И.И. Правовая экзистенциальность биопатентов - насущная проблема современного интеллектуального законотворчества.

Представлена краткая постатейная детализация неоднородности определений биотехнологий как объектов интеллектуальной собственности, а также связанных с ними процессов, в международно-правовых актах. Предпринята попытка исследовать правовую экзистенциальность биопатентов и охарактеризовать значение особенностей сути биотехнологий для обоснования сверхважности обусловленности процедуры патентования, учитывая данную специфику на этапе создания отечественной нормативно-правовой основы. Частично раскрыты подходы международно-правовых актов в части закрепления принципов охраны и защиты прав интеллектуальной собственности на биотехнологии, как в приоритетной научно-экономической и государственно-стратегической области, определены особенности их реализации в национальном законодательстве.

Указано на предостережения о возможных созданных разрушительных последствиях современного некомпетентного подхода со стороны отечественных законодателей к сущности состава биотехнологий, как объектов интеллектуальной собственности, в создании механизмов интеллектуального законотворчества, учитывая уникальную способность биотехнологий саморепродуцироваться и самовоспроизводиться. Отмечены существенные изменения в постепенном приближении правовых нормативов к стандартам системы права Европейского сообщества в обеспечении охраны прав интеллектуальной собственности на биотехнологии. Отражено понимание необходимого выделения биотехнологий в самостоятельную правовую локальную интеллектуальную сферу цивилизации с соответствующим уровнем ответственности в перспективе появления ключевой инновационной правовой модели при унифицированной законотворческой спирали.

Ключевые слова: правовая экзистенциальность, интеллектуальное законотворчество, система права ЕС, трансформация, гармонизация, биотехнологии, уникальность, специфичность, биопатенты, некомпетентность, предостережения.

\section{Summary}

\section{Iryna Kuzmych. Legal existentiality of bio-patents is an urgent problem of modern intellectual law-making.}

This article presents a brief, detailed breakdown of the heterogeneity of definitions of biotechnology, as objects of intellectual property, as well as related processes, in international legal acts of the European Parliament, the Council of the EU and the European Community, an attempt has been made to investigate the legal existentiality of biopatents and to characterize the importance of features of the essence of biotechnology, to substantiate the extreme conditionality of the procedure for patenting biotechnology, taking into account this specificity at the stage of creating a national regulatory framework, laid down in the main national regulations. The approaches of international legal acts regarding the consolidation of the principles of protection and protection of intellectual property rights, in particular, and, above all, on biotechnology, as in the a priority scientific, economic and state - strategic sphere, are partially disclosed and the peculiarities of their implementation in national legislation are defined. The warnings about the possible devastating consequences of the current incompetent approach by domestic legislators to the essence of biotechnology as objects of intellectual property, creation of mechanisms of intellectual lawmaking, given their unique ability to self-reproduce and self-reproduce, are pointed out. However, at the same time, it has been noted so far that there have been significant changes in the gradual approximation of legal standards to the standards of the European Community law system, in particular, in ensuring the protection of intellectual property rights in biotechnology, which will have a beneficial effect on the prospect of the emergence of a key innovative legal model with a unified legislative spirals with an understanding of the necessary separation of biotechnologies into an independent legal local intellectual sphere of civilization with an appropriate level of responsibility. 
The multifaceted nature of the content of biotechnology has turned a science that studies the possibilities of using living organisms, their systems or their vital products to solve technological problems, as well as the possibility of creating living organisms with the necessary properties by genetic engineering, into one of the areas of industry of important macroeconomic importance. In all leading countries of the world, national and international programs on biotechnology, funded by public and private capital, are developed and are operating, in addition, the results of scientific research in the field of biotechnology. Implement long-term projects with a high degree of risk upon receipt of various commercial products, the development results of which must be reliably protected from competitors, possibly while ensuring the granting of exclusive rights to new products and technologies by patenting. Thus, the protection of the right to biotechnology makes the patent an instrument for transferring technology and protecting new markets in the global economy, where the use of such an instrument is most effective in industries with a high cost of research and development, but low production cost of the final product, typical for biotechnological, microbiological and pharmaceutical industry.

Convincingly, even in a quote by A. Einstein, «Nature shows us only the tail of the lion. But I do not doubt that the lion belongs to it even though he cannot at once reveal himself because of his enormous size», there are warnings regarding a negligent attitude towards the natural uniqueness of biotechnologies and an understanding of the devastating consequences of an incompetent approach to the interpretation of the concepts and processes associated with biotechnologies when creating a domestic regulatory and legal framework for the protection of intellectual property rights in biotechnologies, the need for biopatents, taking into account the supremacy and legal existence of biotechnologies, as objects of intellectual property and a powerful generator of scientific and technological development ia of the country, the guarantor of innovation and financial stability, and, the innermost unexplored possibilities of biotechnology with unpredictable prospects for humanity.

Key words: legal existentiality, intellectual lawmaking, EU law system, transformation, harmonization, biotechnology, uniqueness, specificity, biopatents, incompetence, reservations. 